Faculty of Mathematics and Computer Science

Belgrade

CONTACT: jelena.stojanovic@alfa.edu.rs

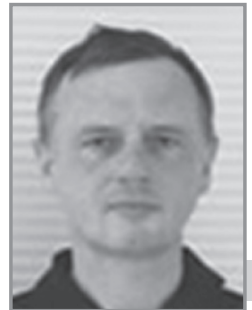

\title{
Zoran NEŠIĆ
}

Faculty of Technical Sciences Čačak

CONTACT: zoran.nesic@ftn.kg.ac.rs

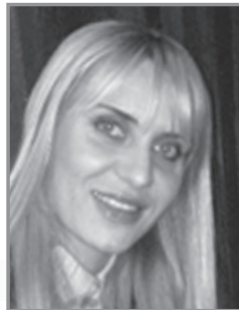

\section{Ivana BULUT} BOGDANOVIĆ

Faculty of Social Sciences Belgrade

CONTACT: ivana.bulut@fdn.edu.rs

\section{DIGITALIZATION OF EDUCATION IN THE FUNCTION OF ECONOMIC DEVELOPMENT ${ }^{1}$}

Abstract: This paper conducts theoretical and empirical research with the aim of analyzing the opportunities provided by digitalized education systems and the use of modern technologies in education in the current economic crisis and global pandemic and how it affects the process of teaching and developing future needs of the workforce towards developing economies. The fundamental goal of this paper is a meticulous study of the impact of digital literacy on the digitalization of education and the use of new approaches in teaching and learning to develop knowledge, abilities and skills by which the economy should improve business efficiency and effectiveness.

Keywords: MODERN TECHNOLOGIES, DIGITALIZATION, EDUCATION, CURRENT ECONOMIC CRISIS, ECONOMIC DEVELOPMENT. 


\section{Introduction}

An introduction to a thesis that studies the digitalization of education and how technology and new methods of education affect the development of skills and competencies of the workforce required by the economy in the 21st century based on knowledge, information and new technologies is presented at the beginning of the paper. In response to the needs of society for a qualified random force that will be ready to jump immediately into the process of production of goods and services, the term Dual Education appears, which is part of the system of secondary education in which, through theoretical teaching and exercises in school, and learning through work with an employer, students acquire, improve and build knowledge, skills and abilities and attitudes (competencies) in accordance with the qualification standard and the curriculum. In that sense, the employer is a legal or natural person who meets the prescribed conditions for learning through the work of students in dual education and whose activity enables the realization of the contents prescribed by the appropriate curriculum. This form of learning is also known as "learning through work" which is an organized process during which students, under the guidance and supervision of instructors in a real work environment with the employer, acquire the competencies necessary for efficient and productive work in the occupation or group of occupations. (the Draft on Dual Education of the Republic of Serbia)

Recent research indicates that knowledge is being developed and used in new ways today, enabling a shorter development cycle and more innovation, given that knowledge and the ability to innovate are elements that provide a long-term competitive advantage. Here we can cite the research of Stanford University that nowadays knowledge doubles every couple of years, changes are so fast that workers must constantly develop new abilities and skills and thus become the most important factor of production. Another characteristic is that more and more work will be done via the Internet, which is best confirmed by the current situation with the global pandemic.

\section{Basic principles and objectives of dual education}

The relevant literature emphasizes that the goal of the education system is to provide more basic literacy to most students, the skills that are easiest to learn and the best way to assess abilities.

In addition, students should focus their attention on educational institutions in order to develop the cognitive abilities necessary for the functioning of the 21st century economy (Soland, Hamilton \& Stecher, 2013). 
Zoran NEŠIĆ

Faculty of Technical Sciences Čačak

\section{Ivana BULUT BOGDANOVIĆ}

Faculty of Social Sciences

Belgrade

The basic principles of dual education are (the Draft on Dual Education of the Republic of Serbia):

1) accessibility - equal conditions for all for quality access to dual education;

2) relevance - compliance with the needs of employers and the labor market;

3) mobility - access to different areas of work within the same and higher levels of education;

4) lifelong learning - enabling education and development throughout life in all areas of life and work;

5) the right to choose - the freedom to choose an occupation and educational profile within the established criteria;

6) equal opportunities - acquisition of education regardless of gender, racial, national, cultural, ethnic and religious affiliation, language, sexual orientation, place of residence, financial status and other personal characteristics;

7) partnership - cooperation of state administration bodies, autonomous provinces, local government units, institutions and other organizations responsible for development, provision and improvement of the quality of education and upbringing and employment, scientific research organizations, as well as social partners - chambers of commerce, representative associations, professional associations of employers, trade unions, associations of citizens and individuals;

8) professionalism and ethics - the responsibility of schools and employers to achieve the goals and principles of dual education and respect for the personality and dignity of each student;

9) quality assurance - ensuring the achievement of the necessary standards in all activities of dual education.

In addition to formal education, it is increasingly necessary today to apply a lifelong learning approach. In this regard, in order to equip students with skills, the requirements for model restructuring appear in lifelong learning models, which are not limited to formal education, but also include non-formal learning with access to technologies and learning opportunities anywhere, at any time (TechKnovLogia, 2013 ).

The main objectives of dual education are (the Draft on Dual Education of the Republic of Serbia):

1) providing conditions for acquiring, improving and developing competencies in accordance with the needs of the labor market;

2) providing conditions for further education and lifelong learning;

3) development of entrepreneurship, innovation, creativity, professional and career development of each individual;

4) providing conditions for personal, economic and general social development; 
5) developing the ability for teamwork and a sense of personal responsibility in work;

6) developing awareness of the importance of health and safety, including safety and health at work;

7) developing the ability of self-evaluation and expression of one's own opinion as well as independent decision-making.

One of the basic preconditions for successful realization of quality dual education is digital literacy. Some authors point out that teachers increasingly know that they do not help students to develop and use digital capacities in the process of education (Johnson, Adams \& Haivood, 2011).

However, other authors point out that pupils and students today use digital devices and resources that enable them to communicate quickly and learn and have fun both at home and at school and at work (Vankel, Marovich \& Stanaitite, 2010).

Another very important factor in education, given the growing amount of data and information that today's education systems encounter, is analysis. One of the key trends in the future of education is the use of effective analytical tools with the aim of analyzing a large amount of data that help improve the learning process. The data analyst will be used as a basis for transforming education by improving education systems and educational institutions through

1. efficient allocation of resources and fulfillment of the curriculum,

2. assessment of learning success and teaching quality,

3. supporting students' progress and students' success.

The relevant literature emphasizes that the responsibility for education lies in the transfer of knowledge, which is relevant from the perspective of the labor market, to students, so it is important that the education system monitors what must happen in the labor market and provides appropriate and quality education (Perez, Kozovska \& Garrouste, 2010).

In that sense, the key competencies are those that will explain success in the modern economy, critical thinking, analytical skills and problem-solving abilities.

At the same time, some authors emphasize that due to rapid technological changes and changes in the economy, skills are becoming increasingly important for employers, such as teamwork and team management skills (Pellegrino \& Hilton, 2012). 


\section{Zoran NEŠIĆ}

Faculty of Technical Sciences Čačak

\section{Ivana BULUT BOGDANOVIĆ}

Faculty of Social Sciences

Belgrade

It is very important to define the scope and manner of learning in dual education (the Draft on Dual Education of the Republic of Serbia). The scope of learning through work with the employer for educational profiles for a period of three years represents at least 50 percent of the total number of hours of compulsory professional subjects prescribed by the curriculum. The scope of learning through work with the employer for educational profiles in the four-year duration represents at least 45 percent of the total number of hours of compulsory professional subjects prescribed by the curriculum. Learning through work with the employer can be done during the entire school year in the period from 8 to 20 hours, for a maximum of eight hours a day or a maximum of 35 hours a week, in accordance with the curriculum. On-the-job training is performed by the employer in its entirety. Part of learning through work can also be performed in a school workshop if it is provided by the curriculum, i.e. if it is not possible to achieve it in its entirety with the employer. If part of the learning through work is performed in a school workshop, the school must have the materials and equipment necessary for the realization of the part of learning through work that could not be achieved by the employer. The school is allowed to realize a maximum of 20 percent of the number of teaching hours through the work provided by the curriculum.

Some authors point out that the system to develop knowledge and skills required by the economy, and thus easier and faster employment of graduates, includes activities such as: monitoring and projection needs of knowledge and skills economies, cooperation with companies in formulating educational programs, integrating practical programs and increasing the flexibility of educational programs (Savova, 2012).

This is followed by the opinion that the cooperation of the education system and the economy enables the creation of educational programs that help to follow the needs of the economy for knowledge and skills (Heali, Perkman, Goddard \& Kempton, 2014).

These are conditions that the employer must meet in order to perform learning through work (the Draft on Dual Education of the Republic of Serbia):

1) performing activities that enable the realization of the content of learning through the work prescribed by the appropriate curriculum;

2) disposal of space, equipment and means for work in accordance with the rulebook on detailed conditions regarding space, equipment and teaching aids of a certain educational profile;

3) disposal of the required number of licensed instructors in accordance with the curriculum;

4) ensuring the application of safety and health measures at work;

5) that no bankruptcy proceedings have been opened or liquidation proceedings 
have been initiated against the employer;

6) that the responsible person has not been legally convicted by the employer for criminal offenses from the group of criminal offenses against: life and body; freedom and rights of a man and citizen; labor rights; parts and reputation; full freedom; marriage and family; intellectual property; property; economy; human health; general security of people and property; computer data security; constitutional order and security of the Republic of Serbia; state bodies; justice; public order and peace; legal transactions; official duties; humanity and other goods protected by international law and the Serbian Army.

According to authors Davei, Baaken, Muros and Meerman (2011), the integration of the education system and the economy is important from the perspective of benefits for students, students and companies, as well as for educational institutions, this cooperation increases employment opportunities. One such activity is professional practice which, as a part of the educational program, enables pupils and students to develop generic skills and therefore increase their employability (Heali et al., 2014).

The integration of dual education factors will contribute to greater competitive advantage in the future and increase competition between high schools, universities and businesses, improve the matching of knowledge and skills with labor market needs, promote research, development and innovation and facilitate knowledge transfer (Pavlin, Pavlin and Rakovska 2014).

Open learning materials are very important in modern education precisely because open learning materials are in digital form, you can also include activities to support different forms of learning, such as reading, listening, editing and collaborating (Johnson et al., 2011). The goal of open technologies and content is to make materials for educational purposes freely available, open to editing and transformation (Johnson, Adams, Estrada \& Freeman, 2014b).

Cloud Computing: Anytime, anywhere over a network, it gives you easy and fast access to a group of Adaptive Shared Computing Resources (networks, storage systems, applications, and services) that are available quickly and with minimal management costs or minimal interaction.

The reason why it is so important that cloud computing will be even more important in the near future, which opens the door to greater flexibility, more space, greater collaboration and more creative use of unlimited online resources in classrooms (Johnson et al., 2011). Educational institutions are introducing similar strategies based on cloud computing, to encourage participation, productivity, and mobility in learning (Johnson et al., 2014). 
Zoran NEŠIĆ

Faculty of Technical Sciences Čačak
Ivana BULUT BOGDANOVIĆ

Faculty of Social Sciences

Belgrade

Mobile learning: According to UNESCO (2014), the definition of m-learning implies the use of mobile devices, both separately and in combination with other ICT and orientation in enabling or providing learning anywhere and anytime.

Using the device, pupils and students can access educational resources, create learning content and interconnect and participate in the classroom or outside the classroom (Moura \& Carvalho, 2008).

In the m-learning process it is possible for pupils and students to take control of learning and direct towards achieving learning goals, and choosing the time, place and pace of learning.

On the other hand, the m-learning teacher enables students to offer individual ways of learning, in order to improve their knowledge, abilities and competencies (Driscoll \& Barneveld, 2015). The use of mobile devices brings many benefits, because devices allow different ways of communicating, solving problems and simulating real situations, and through them we can connect with social media, collaborate, share various files and view materials and teaching resources (Driscoll \& Barneveld, 2015; Hockley 2013). Students can use virtual bookmarks to tag important pages, bookmark and record excerpts, search for words and verify their meaning, and perform other tasks on your mobile device (Johnson et al., 2011).

Recent experiences for the global pandemic necessitating the application of educational software have significant benefits in communication.

Just as companies use specialized software to facilitate business, so educational institutions are faced with the ease of communicating with their students, teachers, schools and other interested partners and stakeholders, the learning process becomes a friendly form of learning and sharing information and knowledge in order to achieve the efficient transfer of a wide range of knowledge, abilities and skills that employers require from graduate students, (Cortada et al., 2012).

In this sense, some authors emphasize the importance of introducing social media into education, as it allows each individual to access the Internet.

You can contribute your ideas, views and experiences to a wide range of existing knowledge (Richardson, 2010), so that social media become an urgent and necessary tool in the learning of today's students (Wankel, 2009).

Eminent authors point out that the introduction of social software intended for professional use effectively increases the quality of teaching and learning through 
(Cortada et al., 2012):

1. share of comments and insight into teaching materials,

2. building group dynamics in educational processes,

3. use of games for assessment and evaluation,

4. inclusion of modern simulation methods to provide practical experience,

5. providing constant access to teachers of certain subjects, inclusion of a large number of experienced teachers in joint promotion and innovative teaching,

6. use of tools, such as video and multimedia,

7. greater interaction and cooperation of students, by monitoring success and progress.

The use of modern technologies enables the transfer of digital experiences from the private lives of students in the educational process, simplifies the learning process, enables cooperation among students, provides new approaches to learning, including access to mobile applications and social media, while enabling development of knowledge, abilities and skills needed in today's labor market, which will be increasingly in demand in the future (Johnson et al., 2011).

\section{Conclusion}

The results of the research indicate that the basic role of the educational system is to give pupils and students basic understanding of practical skills and knowledge in order to prepare them for the labor market. Businesses and business systems in the environment that for some reason are not yet digitized, will sooner or later have to think about new ways of doing business, which means that for the efficient functioning of the labor market, new usable practical knowledge is definitely needed. The use of modern technologies (mobile devices, internet and social software) in education contributes to the development and improvement of the need for practical skills that are necessary in the economy and which will enable students to be competitive, which will therefore cause prosperity of the entire economy. Modern theorists of education suggest combined forms of education, where they approach traditional teaching and current e-learning. Modern forms of teaching based on the mass use of ICT have brought numerous advantages, such as various forms of communication, simulation of real situations and being connected to social media. The basic thesis of this paper is that the education system is digitized and uses new approaches, technologies and entrepreneurial business in education, which leads to more competitive training of employees and, therefore, achievement of greater competitive advantages of the economy.

One of the key tasks of the education system must include close interconnection and cooperation of educational institutions with companies and other organizations at all levels of education. Through the integration of pupils and students into the 
Zoran NEŠIĆ

Faculty of Technical Sciences

Čačak

\section{Ivana BULUT BOGDANOVIĆ}

Faculty of Social Sciences

Belgrade

world of adults, companies achieve comprehensive learning, students are included in the labor market, and really represent what is happening there, which means long-term easier transition from the education system to the real economy.

From the existing and emerging trends in education, it is obvious that the role of the education system is changing, which no longer only provides basic skills, but also that students and educational institutions themselves must concentrate on training in developing practical skills for students important for the economy of the 21 st century, while relying on the ability to adapt to rapid changes in business (Soland, Hamilton \& Stecher, 2013).

Modern business or economy requires constant and rapid adaptation to change, which makes it a key factor in education to keep pace with change, so the education system must be out of the classical educational framework and focused on new ways and procedures that will develop and continue to build on skills needed for efficient functioning of the labor market in the future, which also includes flexibility and rapid adaptation to change. 


\section{LITERATURE}

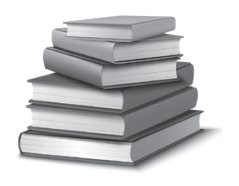

1. Cortada J. W., Lesser E. \& Korsten P. J. (2012): The Business of Social Business: What Works and How it's Done, Executive Report; IBM Institute for Business Value.

2. Davey T., Baaken T., Muros G. V. \& Meerman A. (2011): The State of European

3. University-Business Cooperation: Part of the DG Education and Culture Study on the Cooperation between Higher Education Institutions and Public and Private Organisations in Europe; Münster: Science-to-Business Marketing Research Centre.

4. Denić N., Ivkovic R., Milićević V. (2015): Information and communication technologies and teachers, Scientific anniversary conference with international participation 20; Stara Zagora: Trakia University.

5. Denić N. i Janković S. (2017): Possible aspects of ICT teaching methodology, International Scientific Conference on Recent Advances in IT, Tourism, Economics, Management and Agriculture - ITEMA 2017; Budapest: Association of Economists and Managers of the Balkans; pp. 61-66.

6. Denić N., Obradović D., Obradović D. (2019). Informacione tehnologije za stratešku sposobnost i nadzor rada, Informacione tehnologije, obrazovanje i preduzetništvo ITOP19, Čačak: Fakultet tehničkih nauka u Čačku; pp.283-282.

7. Denić N., Petković D., Ilic M., Milić S. (2017): Possibilities of application e-education in the function of improving the quality of higher education, $17^{\text {th }}$ International Multidisciplinary Scientific GeoConference SGEM 2017, Vol. 17, Issue 54; pp. 151-158.

8. Denić N., Petkovic D., Jovanović N. (2017). Improving teaching process by applying information-communication technology, Annals of the University of Oradea, Fascicle of Management and Technological Engineering, Issue 3; pp. 26-31.

9. Denić N., Zivic N., Spasić B. (2014): Application of information and communication techologies in school education, Annals of the University of Oradea, Fascicle of Management and Technological Engineering; CNCSIS "Clasa B+", ISSUE \#2.

10. Denić N., Živić N., Stevanović V. (2015): Application of information technology in the function of environmental protection, Scientific anniversary conference with international participation 20 years; Stara Zagora: Trakia University.

11. Denić N. i Zlatković D. (2017): A study of the potentials of the distance learning system, International Conference on Science and Education Antalya, Turkey.

12. Driscoll M. \& Barneveld A. (2015); Applying Learning Theory to Mobile Learning, TD at Work: Learning Technologies, 32(1501); pp. 1-16.

13. Gavrilović S., Denić N., Miodragović G. (2016): Obrazovni softveri u nastavi matematike, Informacione tehnologije, obrazovanje i preduzetništvo, ITOP16; Čačak: Fakultet Tehničkih nauka u Čačku; pp. 305-312.

14. Gavrilović S., Krstić M., Denić N., Petrović M., Stevanović V. (2019): Doprinos unapređenju nastave matematike u strukovnim školama - studija slučaja, Informacione tehnologije, obrazovanje i preduzetništvo ITOP19; Čačak: Fakultet Tehničkih nauka u Čačku; pp. 299-304.

15. Healy A., Perkmann M., Goddard J. \& Kempton L. (2014): Measuring the Impact of University-business Cooperation; Luxembourg: Publications Office of the European Union. 


\section{Zoran NEŠIĆ}

Faculty of Technical Sciences

Čačak
Ivana BULUT BOGDANOVIĆ

Faculty of Social Sciences

Belgrade

16. Hockly N. (2013): Designer Learning: The Teacher as Designer of Mobile-based Classroom Learning Experiences; Monterey: The International Research Foundation for English Language Education.

17. Johnson L., Adams B. S., Estrada V. \& Freeman A. (2014): NMC Horizon Report: 2014 K-12 Edition; Austin, Texas: New Media Consortium.

18. Johnson L., Adams S. \& Haywood K. (2011): The NMC Horizon Report: 2011 K-12 Edition; Austin, Texas: New Media Consortium.

19. Milićević V., Denić N., Milićević Z., Arsić Lj. (2016): Uticaj primene informacionih tehnologija na kvalitet obrazovanja, Međunarodna naučno-stručna konferencija "Kako do kvalitetnijeg života", MEF, Beograd; str. 309-315.

20. Moura A. \& Carvalho A. A. (2008, 1.-5. juli): Mobile Learning: Teaching and Learning with Mobile Phones and Podcasts, Eighth IEEE International Conference on Advanced Learning Technologies, Santander, Cantabria; pp. 631-633.

21. Pellegrino J. W. \& Hilton M. L. (2012): Education for life and work: Developing transferable knowledge and skills in the $27^{\text {St }}$ century; Washington, DC: The National Academies Press.

22. Perez E. A., Kozovska K. \& Garrouste C. (2010): Towards a Benchmark on the Contribution of Education and Training to Employability: a discussion note; Luxembourg: Publications Office of the European Union.

23. Richardson, W. (2010): Blogs, Wikis, Podcasts, and Other Powerful Tools for the Classroom; California: Corwin.

24. Savova, I. (2012): Europe 2020 Strategy - Towards a Smarter, Greener and More Inclusive EU Economy? Statistics in focus, 39; pp. 1-12.

25. Wankel C. (2009): Management Education Using Social Media; Organization Management Journal, 6(4); pp. 251-262.

\section{WEBOGRAPHY:}

1. Rakovska N., Pavlin S. \& Melink M. (2014): Assessment of Cooperation Between Higher Education Institutions and Employers in Europe; http://www.eurashe.eu/ library/emcosu_assessment- of-cooperation-between-higher-education-institutionsand-employers-in-europe- wp4-report-pdf (Accessed: 20.08.2019.)

2. Soland J., Hamilton L. S. \& Stecher B. M. (2013): Measuring 27st Century Competencies: Guidance for Educators; http://asiasociety.org/files/gcenmeasuring21cskills.pdf (Accessed: 01.02.2013.)

3. TechKnowLogia (2003): Lifelong Learning in the Global Knowledge Economy: Challenges for Developing Countries; http://www.techknowlogia.org/TKL_Articles/ PDF/476.pdf (Accessed: 20.07.2020.)

\section{OTHER SOURCES:}

1. Draft Law on Dual Education of the Republic of Serbia. 


\section{Јелена СТОЈАНОВИЋ}

Факултет за математику

и рачунарске науке

Београд

\section{Зоран НЕШИЋ}

Факултет техничких наука

Чачак

\section{Ивана БУЛУТ БОГДАНОВИЋ}

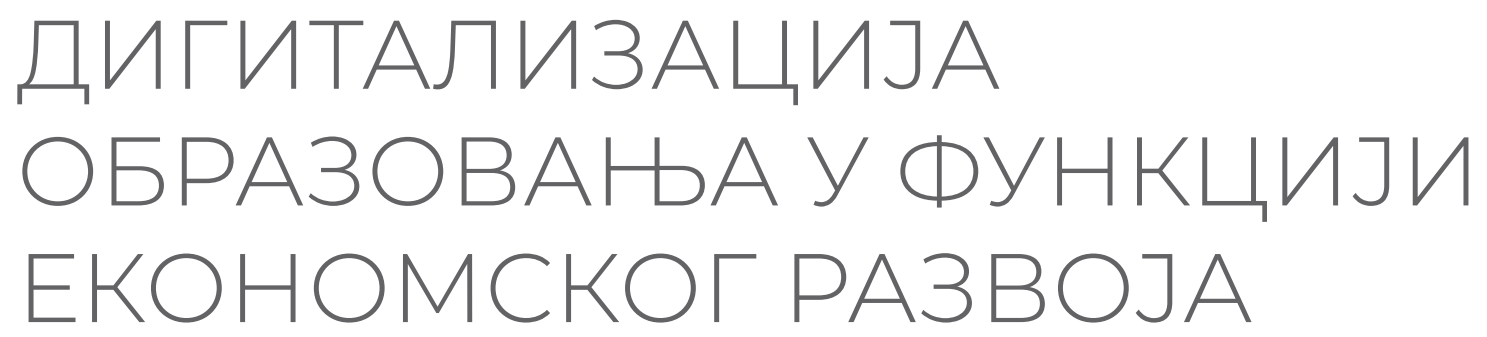

Апстракт: У овом раду је спроведено теоријско и емпиријско истраживање са циљем анализирања које могућности пружају дигитализовани образовни системи и коришћење савремених технологија у образовању у условима актуелне економске кризе и глобалне пандемије и како то утиче на процес подучавања и развој будућих потреба радне снаге у правцу развојних економија. Фундаменлални циљ овог рада је студиозно истраживање утицаја дигиталне писмености на дигитализацију образовања и коришћење нових приступа у настави и учењу за развој знања, способности и вештина којима економија треба да побољша ефикасност и ефективност пословања.

КљУчне речИ: САВРЕМЕНЕ ТЕХНОЛОГИЈЕ, ДИГИТАЛИЗАЦИЈА, ОБРАЗОВАЊЕ, АКТУЕЛНА ЕКОНОМСКА КРИЗА, ЕКОНОМСКИ РАЗВОЈ. 